\title{
Association between open tibia fractures and acute compartment syndrome: a retrospective cohort study
}

\author{
Axel Gamulin ( $\square$ axel.gamulin@hcuge.ch ) \\ Hopitaux Universitaires de Geneve https://orcid.org/0000-0002-0732-7722 \\ Lydia Wuarin
}

Hopitaux Universitaires de Geneve

Matthieu Zingg

Hopitaux Universitaires de Geneve

Patrick Belinga

Hopitaux Universitaires de Geneve

Gregory Cunningham

Hopitaux Universitaires de Geneve

Amanda I. Gonzalez

Hopitaux Universitaires de Geneve

\section{Research article}

Keywords: Tibia fracture, proximal tibia fracture, plateau tibial fracture, tibial shaft fracture, tibial diaphysis fracture, distal tibia fracture, pilon tibial fracture, acute compartment syndrome, open fracture, closed fracture

Posted Date: July 2nd, 2020

DOI: https://doi.org/10.21203/rs.3.rs-37199/v1

License: (c) (1) This work is licensed under a Creative Commons Attribution 4.0 International License. Read Full License

Version of Record: A version of this preprint was published at Orthopaedics \& Traumatology: Surgery \& Research on December 1st, 2021. See the published version at https://doi.org/10.1016/j.otsr.2021.103188. 


\section{Abstract \\ Background}

the aim of this study was to determine if an open tibia fracture is at increased risk to be associated with acute compartment syndrome (ACS), when compared to a closed tibia fracture.

\section{Methods}

a cohort of 711 consecutive adult patients sustaining 725 tibia fractures between January 2005 and December 2009 were included in this retrospective study. The outcome measure was ACS, which was clinically diagnosed. The following variables were assessed: soft tissue condition (closed, open Gustilo type 1 or open Gustilo type 2 and 3); low- vs. high-energy injury; associated contiguous skeletal injury; type of fracture (proximal intra-articular, extra-articular, distal intra-articular). A logistic regression model was used to measure the association between ACS and the variables. Adjustment was performed for age and sex. Statistical significance was defined as $p<0.05$.

\section{Results}

fractures occurred at a mean age of $44.6 \pm 17.4$ years and among $477(65.8 \%)$ men, and ACS occurred in $10.4 \%$ of proximal intra-articular fractures, $10.4 \%$ of extra-articular fractures and $3.3 \%$ of distal intraarticular fractures. ACS occurred in $8.7 \%$ of closed fractures, $7.8 \%$ of open Gustilo 1 fractures and $13.3 \%$ of open Gustilo 2 and 3 fractures. Open fractures were not associated with ACS occurrence when tibia fractures were considered as a whole. When stratifying by types of fractures, open Gustilo 2 and 3 fractures were associated with ACS in proximal intra-articular fractures. No association with closed or any type of open fractures was highlighted for extra-articular fractures. There were not enough ACS cases among distal intra-articular fractures to draw conclusions.

\section{Conclusions}

this study highlighted an association between open Gustilo type 2 and 3 lesions and occurrence of ACS in proximal intra-articular fractures only (AO/OTA 41B and C). This finding must raise the level of suspicion of any surgeon treating this kind of injuries, especially if the patient is intubated, sedated or obtunded. As ACS can occur with any type of open tibia fractures, clinicians should not be wrongly reassured by an open fracture, assuming that the wound would relieve the pressure inside the muscle compartments.

\section{Background}


Fractures of the tibia are common injuries. Proximal tibia fractures represent approximately $1 \%$ of all fractures, tibial shaft fractures approximately $2 \%$, and distal tibia fractures approximately $0.5 \%$ [1]. Tibia fracture spectrum includes a wide range of fracture types, from low-energy undisplaced to high-energy multifragmentary or displaced fractures [2-4]. The energy transmitted to the limb during trauma may also lead to soft-tissue lesions, including skin lacerations (open fractures) and acute compartment syndrome (ACS) [2, 3, 5-7]. Reported risks of ACS are as high as $12 \%$ for overall tibial plateau fractures (even $53 \%$ for some high-energy subtypes) [8-16], and as high as $11.5 \%$ for tibial shaft fractures $[8,12$, 13, 17-19]. The literature is poor about the association of pilon tibial fractures with ACS, and the risk seems relatively low, with two papers reporting an occurrence rate of $2 \%$ and another of $12.5 \%[8,13,20]$.

Studies on the potential association of open tibia fractures and ACS have shown confusing results, with some papers pointing out a positive association, and others failing to do so $[5,7,11-13,16-18,21]$. The aim of this study was therefore to determine if an open tibia fracture is at increased risk to be associated with ACS, when compared to a closed tibia fracture.

\section{Methods}

\section{Ethics statement:}

Before initiation of the study, approval was obtained from the institutional research ethics board.

\section{Study population and design:}

This retrospective cohort study was performed in a 1900-bed urban academic medical center delivering primary to tertiary care to 500,000 inhabitants. All consecutive patients admitted with a tibia fracture were identified using the institutional hospitalization diagnoses database. Inclusion criteria were: 1) a tibial plateau fracture, either intra- or extra-articular (as defined by the AO/OTA classification code 41A2, 41A3, $41 \mathrm{~B}$ or $41 \mathrm{C}$ ), a tibial shaft fracture (as defined by the AO/OTA classification code 42), or a pilon tibial fracture, either intra- or extra-articular (as defined by the AO/OTA classification code 43) [22]; 2) traumatic event causing the fracture; 3) hospital admission between January 2005 and December 2009; 4) definitive treatment in the authors' institution; and 5) age $>16$ years old at the time of injury. At this point, 770 fractures were eligible. Exclusion criteria were: 1) presentation to the authors' institution more than $24 \mathrm{~h}$ after initial trauma (patient-based late presentation or referral from another institution; 28 fractures); 2) pathological or spontaneous (preceding and as cause of the fall) fracture (one fracture); 3 ) periimplant or periprosthetic fracture (10 fractures); 4) open growth plates (four fractures); 5 ) transfer to another institution for definitive treatment (one fracture); 6) above or below the knee amputation within the first 24 hours after the trauma (no occurrence); and 7) death within the first 24 hours after the trauma (one fracture). Finally, 725 fractures in 711 patients were included in the analysis.

\section{Outcome:}

The outcome was development of ACS leading to fasciotomy. Every patient was clinically examined focusing on ACS signs and symptoms at admission and during every preoperative and postoperative 
visit, as well as during surgery. Using the same method as previously published [11, 19], monitoring of intra-compartmental pressure (ICP) was not routinely used to establish ACS diagnosis, but only in selected patients with equivocal clinical signs and those intubated, sedated or obtunded [23-25]. Four compartments fasciotomy was performed when patients had clinical signs of ACS and/or when pathological ICP values were measured (ICP $>30 \mathrm{mmHg}$ or a difference $<30 \mathrm{mmHg}$ between diastolic blood pressure and ICP) $[18,24,26,27]$. Muscle bulging or suffering was evaluated the time of fasciotomy, and their presence or absence reported in the operative notes. In this study, ACS definition was pathological ICP values before fasciotomy and/or presence of muscle bulging or suffering at the time of fasciotomy. The diagnosis of ACS was not confirmed if fasciotomy was performed without prior ICP measurements, and if there was no muscle bulging or suffering at the time of surgery.

\section{Variables of interest}

The main variable of interest (closed or open fracture and Gustilo classification [28, 29] in case of open fractures) was extracted from patients' charts. For statistical analysis, fractures were considered in three categories: closed, Gustilo type 1, and Gustilo type 2 and 3.

Other variables (age, sex, mechanism of injury, type of fracture) were also extracted from patients' charts. Mechanism of injury was further classified as either "fall from own height" or "other" (falls from more than one meter high, road traffic accidents, sports and fight injuries, crushes, construction site accidents) in order to differentiate low- and high-energy trauma.

Fractures were classified following AO/OTA using the initial set of radiographs [22]. They were then stratified into three groups: proximal intra-articular fractures (AO/OTA 41B and C), extra-articular fractures (AO/OTA 41A2 and A3, 42 and 43A) and distal intra-articular fractures (AO/OTA 43B and C). Additionally, the presence or absence of an associated second contiguous skeletal injury was determined, as this variable was highlighted as a risk factor for ACS occurrence in tibial plateau and tibial shaft fractures in two recent publications $[11,19]$. A second contiguous skeletal injury was defined as followed: 1) for proximal tibia fractures, it was either a tibial shaft or pilon fracture (AO/OTA 42 or 43) [22], or a dislocation of both medial and lateral femoro-tibial joint lines [11]; 2) for tibial shaft fractures, it was a second fracture complex located either in the proximal or distal metaphysis (AO/OTA 41 or 43) [22]; for pilon tibial fractures, it was a second fracture complex located either in the proximal metaphysis or in the shaft (AO/OTA 41 or 42) [22].

\section{Statistical analysis:}

Patient and facture characteristics with and without ACS were compared using frequency distributions for discrete variables and mean and standard deviation for continuous variable.

To evaluate the association of the covariates with ACS, we used logistic regression analysis to obtain univariate odds ratios (OR) and $95 \%$ confidence intervals $(95 \% \mathrm{Cl})$. Age was dichotomized at approximate midpoint (age $<$ vs. $\geq 45$ years). 
Because the risk of ACS may be related to the energy dissipated during the impact, and because men and younger patients may be more likely to sustain high-energy impacts, each covariate was then separately adjusted for age and sex using the logistic regression analysis. Statistical significance was defined as $p$ $<0.05$.

IBM ${ }^{\circledR}$ SPSS ${ }^{\circledR}$ Statistics version 19.0.0 software (IBM SPSS, Chicago, IL) was used for statistical analysis.

\section{Results}

Tibia fractures occurred at a mean age of $44.6 \pm 17.4$ years and among $477(65.8 \%)$ men. Overall, ACS occurred in $67(9.2 \%)$ cases; 28 out of 269 (10.4\%) proximal intra-articular fractures, 35 out of 336 (10.4\%) extra-articular fractures and 4 out of 120 (3.3\%) distal intra-articular fractures. Table 1 shows demographics, injury characteristics and clinical, radiographic and treatment factors of the study patients.

Table 1

Demographics, injury characteristics and clinical and radiographic factors of the 711 study patients with 725 fractures

\begin{tabular}{|c|c|c|}
\hline & $\begin{array}{l}\text { ACS absent, } n=658 \\
(90.8 \%)\end{array}$ & $\begin{array}{l}\text { ACS present, } n=67 \\
(9.2 \%)\end{array}$ \\
\hline Age (years) & $45.2 \pm 17.6$ & $37.1 \pm 12.8$ \\
\hline Age < 45 years, $n(\%)$ & $347(52.7 \%)$ & $54(80.6 \%)$ \\
\hline Male sex, n (\%) & $419(63.7 \%)$ & $58(86.6 \%)$ \\
\hline $\begin{array}{l}\text { Mechanism other than fall from own height, } \\
\mathrm{n}(\%)\end{array}$ & $484(73.6 \%)$ & $67(92.5 \%)$ \\
\hline Closed fracture, $\mathrm{n}(\%)$ & $514(78.1 \%)$ & $49(73.1 \%)$ \\
\hline Open fracture Gustilo 1, n (\%) & $59(9.0 \%)$ & $5(7.5 \%)$ \\
\hline Open fracture Gustilo 2 and 3, n (\%) & $85(12.9 \%)$ & $13(19.4 \%)$ \\
\hline Proximal intra-articular fractures $\mathrm{n}(\%)$ & $241(36.6 \%)$ & $28(41.8 \%)$ \\
\hline Extra-articular fractures n (\%) & $301(45.7 \%)$ & $35(52.2 \%)$ \\
\hline Distal intra-articular fractures $\mathrm{n}(\%)$ & $116(17.6 \%)$ & $4(6.0 \%)$ \\
\hline Associated contiguous skeletal injury, n (\%) & $11(1.7 \%)$ & $12(17.9 \%)$ \\
\hline $\begin{array}{l}\text { No associated contiguous skeletal injury, } n \\
(\%)\end{array}$ & $647(98.3 \%)$ & $55(82.1 \%)$ \\
\hline \multicolumn{3}{|c|}{$\begin{array}{l}\text { ACS. acute compartment syndrome. Proximal intra-articular fractures: AO/OTA classification } 41 \mathrm{~B} \text { an } \\
\text { C. Extra-articular fractures: AO/OTA classification } 41 \mathrm{~A} 2 \text { and } \mathrm{A} 3,42 \text { and } 43 \mathrm{~A} \text {. Distal intra-articular } \\
\text { fractures: AO/OTA classification } 43 \mathrm{~B} \text { and C. }\end{array}$} \\
\hline
\end{tabular}


There were 49 ACS out of 563 closed fractures (8.7\%), 5 ACS out of 64 open Gustilo type 1 fractures (7.8\%) and 13 ACS out of 98 open Gustilo type 2 and 3 fractures (13.3\%). Univariate analysis and analysis after adjustment for age and sex did not recognize any soft tissue condition (closed fracture, open fracture Gustilo type 1, open fracture Gustilo type 2 and 3) as associated with ACS occurrence when tibia fractures were considered as a whole (Table 2).

Table 2

Association between variables of interest (demographics, injury characteristics and clinical, radiographic and treatment factors) and occurrence of acute compartment syndrome

\begin{tabular}{|c|c|c|c|c|}
\hline & \multicolumn{2}{|c|}{ Univariate analysis } & \multicolumn{2}{|c|}{$\begin{array}{l}\text { Each variable adjusted for age } \\
\text { and sex*}\end{array}$} \\
\hline & OR (95\% Cl) & $\begin{array}{l}P \\
\text { value }\end{array}$ & OR $(95 \% \mathrm{Cl})$ & $P$ value \\
\hline Age $<45$ years & $\begin{array}{l}3.72(1.99- \\
6.95)\end{array}$ & $\begin{array}{l}<.001 \\
0.00\end{array}$ & - & - \\
\hline Male sex & $\begin{array}{l}3.68(1.79- \\
7.55)\end{array}$ & $<.001$ & - & - \\
\hline $\begin{array}{l}\text { Mechanism other than fall from } \\
\text { own height }\end{array}$ & $\begin{array}{l}4.46(1.76- \\
11.27)\end{array}$ & 0.002 & $2.81(1.09-7.26)$ & 0.033 \\
\hline \multicolumn{5}{|l|}{ Soft tissue condition } \\
\hline Closed fracture & Ref. & & Ref. & \\
\hline Open fracture Gustilo 1 & $\begin{array}{l}0.89(0.34- \\
2.32)\end{array}$ & 0.810 & $0.74(0.28-1.97)$ & 0.551 \\
\hline Open fracture Gustilo 2 and 3 & $\begin{array}{l}1.60(0.84- \\
3.08)\end{array}$ & 0.156 & $1.30(0.67-2.56)$ & 0.440 \\
\hline \multicolumn{5}{|l|}{ Fracture type } \\
\hline Proximal intra-articular fractures & Ref. & & Ref. & \\
\hline Extra-articular fractures & $\begin{array}{l}1.00(0.59- \\
1.69)\end{array}$ & 0.998 & $0.80(0.46-1.37)$ & 0.411 \\
\hline Distal intra-articular fractures & $\begin{array}{l}0.30(0.10- \\
0.87)\end{array}$ & 0.026 & $0.23(0.08-0.68)$ & 0.008 \\
\hline $\begin{array}{l}\text { Associated contiguous skeletal } \\
\text { injury }\end{array}$ & $\begin{array}{l}12.83(5.41- \\
30.42)\end{array}$ & $<.001$ & $9.33(3.80-22.92)$ & $<0.001$ \\
\hline \multicolumn{5}{|c|}{ *Each variable was adjusted for age ( $<45$ years vs. $\geq 45$ years) and sex (male vs. female) } \\
\hline \multicolumn{5}{|c|}{$\begin{array}{l}\text { OR: odds ratio. } 95 \% \mathrm{Cl} \text { : } 95 \% \text { confidence interval. Proximal intra-articular fractures. AO/OTA } \\
\text { classification } 41 \mathrm{~B} \text { and C. Extra-articular fractures: AO/OTA classification } 41 \mathrm{~A} 2 \text { and } \mathrm{A} 3,42 \text { and } 43 \mathrm{~A} \text {. } \\
\text { Distal intra-articular fractures: AO/OTA classification } 43 \mathrm{~B} \text { and C. }\end{array}$} \\
\hline
\end{tabular}


In the univariate analysis, age $<45$ years, male sex, high-energy mechanism of injury (other than fall from own height) and presence of an associated contiguous skeletal injury were associated with higher odds of ACS, and presence of a distal intra-articular fracture was associated with lower odds of ACS (Table 2). After adjustment for age and sex the association with ACS remained (Table 2).

When stratifying by types of tibia fractures, open Gustilo type 2 and 3 injuries were positively associated with ACS occurrence in proximal intra-articular fractures (Table 3). No association with closed or any type of open injuries was highlighted for extra-articular fractures (Table 3). There were not enough ACS cases (four) among distal intra-articular fractures to draw conclusions (Table 3).

Table 3

Association between soft tissue condition and occurrence of acute compartment syndrome, by fracture types

\begin{tabular}{|llll|}
\hline Soft tissue condition & $\begin{array}{l}\text { Proximal intra-articular } \\
\text { fractures } \\
\text { OR }(95 \% \mathrm{Cl}), \mathrm{p} \text { value }\end{array}$ & $\begin{array}{l}\text { Extra-articular } \\
\text { fractures } \\
\text { OR }(95 \% \mathrm{Cl}), \mathrm{p} \\
\text { value }\end{array}$ & $\begin{array}{l}\text { Distal intra-articular } \\
\text { fractures } \\
\text { OR }(95 \% \mathrm{Cl}), \mathrm{p} \text { value }\end{array}$ \\
\hline Closed fracture & Ref. & Ref. & * \\
\hline Open fracture Gustilo 1 & $4.07(0.75-22.23) ; 0.105$ & $\begin{array}{l}0.47(0.13-1.62) ; \\
0.233\end{array}$ & * \\
\hline $\begin{array}{l}\text { Open fracture Gustilo 2 } \\
\text { and 3 }\end{array}$ & $3.39(1.01-11.42) ; 0.048$ & $\begin{array}{l}0.79(0.31-1.62) ; \\
0.628\end{array}$ & $*$ \\
\hline
\end{tabular}

*There were only four cases of acute compartment syndrome among distal intra-articular fractures.

Proximal intra-articular fractures: AO/OTA classification 41B and C. Extra-articular fractures: AO/OTA classification 41A2 and A3, 42 and 43A. Distal intra-articular fractures: AO/OTA classification 43B and C. OR: odds ratio. $95 \% \mathrm{Cl}$. $95 \%$ confidence interval.

\section{Discussion}

This study found an association between ACS and age, sex, mechanism of injury, associated contiguous skeletal injury, and presence of a distal intra-articular fracture. The study did not highlight any soft tissue condition (closed fracture, open fracture Gustilo type 1, open fracture Gustilo type 2 and 3) as associated with ACS occurrence when tibia fractures were considered as a whole. However, after stratification by types of fractures, ACS occurrence was associated with open Gustilo type 2 and 3 injuries in proximal intra-articular fractures only.

The ACS occurrence rates found in this study fall within previously reported rates in the literature, which ranged from $0.7-12 \%$ for tibial plateau fractures (even as high as $53 \%$ for some higher-energy subgroups) [8-16], from 3-11.5\% for tibial shaft fractures [8, 12, 13, 17-19], and from $2-12.5 \%$ for pilon tibial fractures $[8,13,20]$. For this reason, it can be assumed that the study cohort closely represents the 
habitual spectrum of tibia fractures, and that its results might be generalized to most tibia fracture patients.

In the past, there was a wrongly reassuring dogma assuming that an open fracture would protect from the occurrence of ACS by relieving the pressure inside the muscle compartments through the fascial tears. This was shown to be incorrect, as some studies reported ACS occurrences after open tibia fractures $[11-13,16-18,21]$. In the analysis without stratification by fracture type, we did not find any association between ACS occurrence and soft tissue condition. This is mainly due to the 120 distal intraarticular fractures included in the cohort, which had a significantly lower risk of ACS occurrence than other fracture types ( $3.3 \%$ vs. $10.4 \% ; p=0.014$ ) and mitigated differences in the overall results. Indeed, our results showed that distal extra-articular fracture might be a protecting factor against ACS occurrence, when compared to a more proximal location. This finding might be explained by the fact that the distal tibia is surrounded by a less bulkier muscle mass, and that the energy released during trauma is transmitted into tendinous soft tissues rather than muscle, thus less likely leading to the potential development of ACS [19].

In the analysis by fracture types, ACS occurrence was associated with open Gustilo type 2 and 3 injuries in proximal intra-articular tibia fractures only, with a weak significance level (OR 3.39 (95\% Cl 1.01$11.42) ; p=0.048$ ). One previously published paper reported a significant linear association between occurrence of ACS and severity of open fracture in the univariate analysis, which failed to be confirmed after adjustment according to age and sex [11]. Another paper did not show any association between open fracture and ACS even in the univariate analysis [16]. Due to this weak evidence, one cannot definitively assume that an open skin lesion is associated with a higher risk of ACS occurrence in case of proximal intra-articular tibia fractures. However, the physician in charge should be aware of these findings, and should actively look for signs and symptoms of ACS development when treating open fractures.

No association with closed or any type of open injuries was highlighted for extra-articular tibia fractures. This means that open tibial shaft fracture was recognized neither as a risk factor nor as a protecting factor for ACS occurrence. This finding is in line with previously published research [13, 17-19]. However, two older publications recognized open tibial shaft fractures as positively associated with the occurrence of ACS, with open fracture severity directly proportional to ACS incidence $[5,21]$. In this fracture type also, the physician in charge should be aware of these findings, and should actively look for signs and symptoms of ACS development.

There were not enough ACS cases (four) among distal intra-articular tibia fractures to draw any conclusions. The association of ACS with open fractures of the pilon tibial has not been investigated in a well-conducted study yet. To the best of the authors' knowledge, there is only one case-report available in the literature citing increased soft tissue damage as a potential risk factor for ACS occurrence after pilon tibial fracture; however in this paper, this statement was not evidence-based and it was not specified if increased soft tissue damage included open fractures [7]. 
Despite being the largest series to date analyzing the association between soft tissue injury and the development of ACS in tibia fractures, this paper suffers several limitations: 1) this study was prone to several biases inherent to its retrospective design, and to some inexactitude in patients' charts that were reviewed to extract variables of interest; 2) ICP measurements, which would have been the gold standard to diagnose or exclude ACS, were performed only on a subset of patients, thus introducing the possibility of false positive or false negative diagnosis; however, we did not find any clinical records suspect of late ACS sequelae in the charts of patients that were not diagnosed with ACS, and every patient who underwent fasciotomy had pathological ICP values before fasciotomy, and/or presented muscle bulging or suffering at the time of fasciotomy; 3 ) the tibia fracture stratification that was used does not strictly follow the AO/OTA classification; however, we felt that an AO/OTA 41A2 or A3 fracture was closer to an AO/OTA 42 fracture than to an AO/OTA 41B or $C$ fracture in terms of fracture line anatomy and absence of articular involvement, and we choose to stratify fractures following this method.

\section{Conclusions}

This study highlighted a weak association between open Gustilo type 2 and 3 lesions and occurrence of ACS in proximal intra-articular fractures only (AO/OTA 41B and C). This finding must raise the level of suspicion of any surgeon treating this kind of injuries, especially if the patient is intubated, sedated or obtunded at the time of assessment. Importantly, this study confirmed that clinicians must not be wrongly reassured by an open fracture, assuming that the wound would relieve the pressure inside the muscle compartments, as ACS may still develop in open fractures. In fact, skin wounds in the vicinity of a fracture should be recognized as a direct sign of increased amount of underlying fascial and muscle injury and must not be underestimated by the treating physician.

\section{Abbreviations}

$95 \% \mathrm{Cl}$

95\% confidence intervals

ACS

acute compartment syndrome

AO/OTA

Arbeitsgemeinschaft für Osteosynthesefragen / Orthopaedic Trauma Association

ICP

intra-compartmental pressure

OR

odds ratios

\section{Declarations}

Ethics approval and consent to participate: before initiation of the study, approval was obtained from the institutional research ethics board (Commission Centrale d'Ethique de la Recherche sur l'Etre Humain des 
Hôpitaux Universitaires de Genève, reference number 10-190 / NAC 10-063). All procedures performed in studies involving human participants were in accordance with the ethical standards of the institutional and/or national research committee and with the 1964 Helsinki declaration and its later amendments or comparable ethical standards. For this type of study formal consent to participate is not required.

Consent for publication: not applicable.

Availability of data and material: the datasets used and/or analyzed during the current study are available from the corresponding author on reasonable request.

Competing interests: the authors declare that they have no competing interests.

Funding: there was no external source of funding or financial support for this study.

Authors' contributions: AG carried out the conception and design of the study, was the major contributor for the acquisition and interpretation of data and drafted and critically revised the manuscript. LW contributed to the acquisition and interpretation of data and critically revised the manuscript. MZ contributed to the interpretation of data and critically revised the manuscript. PB contributed to the acquisition and interpretation of data and critically revised the manuscript. GC contributed to the acquisition and interpretation of data and critically revised the manuscript. AIG carried out the conception and design of the study, performed the statistical analysis, was the major contributor for the interpretation of data and drafted and critically revised the manuscript. Finally, all authors gave their final approval of the version to be published. They all agree to be accountable for all aspect of the work in ensuring that questions related to the accuracy or integrity of any part of the work are appropriately investigated and resolved.

Acknowledgements: not applicable.

\section{References}

1. Court-Brown CM, Caesar B. Epidemiology of adult fractures: A review. Injury. 2006;37:691-7.

2. Bartlett CS III, Weiner LS. Fractures of the tibial pilon. In: Browner BD, Jupiter JB, Levine AM, Trafton PG, Krettek C, editors. Skeletal trauma: basic science, management, and reconstruction. 3rd ed. Philadelphia: Saunders Elsevier; 2003. pp. 2257-306.

3. Cole P, Levy B, Watson JT, Schatzker J. Tibial plateau fractures. In: Browner BD, Jupiter JB, Levine AM, Trafton PG, Krettek C, editors. Skeletal trauma: basic science, management, and reconstruction. 4th ed. Philadelphia: Saunders Elsevier; 2009. pp. 2201-87.

4. Trafton PG. Tibial shaft fractures. In: Browner BD, Jupiter JB, Levine AM, Trafton PG, Krettek C, editors. Skeletal trauma: basic science, management, and reconstruction. 3rd ed. Philadelphia: Saunders Elsevier; 2003. pp. 2131-255. 
5. Blick SS, Brumback RJ, Poka A, Burgess AR, Ebraheim NA. Compartment syndrome in open tibial fracture. J Bone Joint Surg [Am]. 1986;68-A:1348-53.

6. Borrelli J Jr. Management of soft tissue injuries associated with tibial plateau fractures. J Knee. 2014;27:5-9.

7. Patillo D, Della Rocca GJ, Murtha YM, Crist BD. Pilon fractures complicated by compartment syndrome: a case report. J Orthop Trauma. 2010;24:e54-7.

8. Allmon C, Greenwell P, Paryavi E, Dubina A, O'Toole RV. Radiographic predictors of compartment syndrome occurring after tibial fracture. J Orthop Trauma. 2016;30:387-91.

9. Barei DP, Nork SE, Mills WJ, Henley MB, Benirschke SK. Complications associated with internal fixation of high-energy bicondylar tibial plateau fractures utilizing a two-incision technique. J Orthop Trauma. 2004;18:649-57.

10. Egol KA, Tejwani NC, Capla EL, Wolinsky PL, Koval KJ. Staged management of high-energy proximal tibia fractures (OTA types 41): the results of a prospective, standardized protocol. J Orthop Trauma. 2005;19:448-55.

11. Gamulin A, Lübbeke A, Belinga P, Hoffmeyer P, Perneger TV, Zingg M, Cunningham G. Clinical and radiographic predictors of acute compartment syndrome in the treatment of tibial plateau fractures: a retrospective cohort study. BMC Musculoskelet Disord. 2017;18:307.

12. Menetrey J, Peter R. [Acute compartment syndrome in the post-traumatic leg]. Rev Chir Ortho Reparatrice Appar Mot. 1998;84:272-80.

13. Park S, Ahn J, Gee AO, Kuntz AF, Esterhai JL. Compartment syndrome in tibial fractures. J Orthop Trauma. 2009;23:514-8.

14. Stark E, Stucken C, Trainer G, Tornetta P 3. Compartment syndrome in Schatzker type VI plateau fractures and medial condylar fracture-dislocations treated with temporary external fixation. J Orthop Trauma. 2009;23:502-6. rd. .

15. Wahlquist M, laguilli N, Ebraheim N, Levine J. Medial tibial plateau fractures: a new classification system. J Trauma. 2007;63:1418-21.

16. Ziran BH, Becher SJ. Radiographic predictors of compartment syndrome in tibial plateau fractures. J Orthop Trauma. 2013;27:61-5.

17. McQueen MM, Duckworth AD, Aitken SA, Sharma RA, Court-Brown CM. Predictors of compartment syndrome after tibial fracture. J Orthop Trauma. 2015;29:451-5.

18. Shadgan B, Pereira G, Menon M, Jafari S, Darlene Reid W, O'Brien PJ. Risk factors for acute compartment syndrome of the leg associated with tibial diaphyseal fractures in adults. J Orthop Traumatol. 2015;16:185-92.

19. Wuarin L, Gonzalez Al, Zingg M, Belinga P, Hoffmeyer P, Peter R, Lübbeke A, Gamulin A. Clinical and radiographic predictors of acute compartment syndrome in the treatment of tibial shaft fractures: a retrospective cohort study. BMC Musculoskelet Disord. 2020;21:25. 
20. Court-Brown CM, Walker C, Garg A, McQueen MM. Half-ring external fixation in the management of tibial plafond fractures. J Orthop Trauma. 1999;13:200-6.

21. DeLee JC, Stiehl JB. Open tibia fracture with compartment syndrome. Clinical Orthop Relat Res. 1981;160:175-84.

22. Kellam JF, Meinberg EG, Agel J, Karam MD, Roberts CS. Fracture and Dislocation Classification Compendium-2018. J Orthop Trauma. 2018;32(Suppl 1):1-170.

23. Amendola A, Twaddle BC. Compartment syndromes. In: Browner BD, Jupiter JB, Levine AM, Trafton $P G$, Krettek $C$, editors. Skeletal trauma: basic science, management, and reconstruction. 3rd ed. Philadelphia: Saunders Elsevier; 2003. pp. 268-92.

24. Gorczyca JT, Roberts CS, Pugh KJ, Ring D. Review of treatment and diagnosis of acute compartment syndrome of the calf: current evidence and best practices. Instr Course Lect. 2011;60:35-42.

25. Südkamp NP. Soft-tissue injury: pathophysiology and its influence on fracture management Evaluation/classification of closed and open injuries. In: Rüedi TP, Murphy WM, editors. AO principles of fracture management. 2nd ed. Stuttgart: Thieme; 2007. pp. 86-113.

26. Gulli B, Templeman D. Compartment syndrome of the lower extremity. Orthop Clin North Am. 1994;25:677-84.

27. McQueen MM, Court-Brown CM. Compartment monitoring in tibial fractures - the pressure threshold for decompression. J Bone Joint Surg [Br]. 1996;78-B:99-104.

28. Gustilo RB, Anderson JT. Prevention of infection in the treatment of one thousand and twenty-five open fractures of long bones: retrospective and prospective analyses. J Bone Joint Surg [Am]. 1976;58-A:453-8.

29. Gustilo RB, Mendoza RM, Williams DN. Problems in the management of type III (severe) open fractures: a new classification of type III open fractures. J Trauma. 1984;24:742-6. 